\title{
Percent Injected Dose
}

National Cancer Institute

\section{Source}

National Cancer Institute. Percent Injected Dose. NCI Thesaurus. Code C94948.

Indicated as \%ID, the amount of activity present in a region or org an as a $\%$ of total available injected activity or dose. 